\title{
Online Teaching during COVID-19 Pandemic in Zambian Universities: Unpacking Lecturers' Experiences and the Implications for Incorporating Online Teaching in the University Pedagogy
}

\author{
Enala Sharon Lufungulo ${ }^{1 *}$, Kennedy Mwila1, Steward Mudenda ${ }^{2}$, Martin Kampamba ${ }^{2}$, \\ Martha Chulu' ${ }^{3}$ Christabel Nang'andu Hikaambo ${ }^{2}$ \\ ${ }^{1}$ Graduate School of Education, Peking University, Beijing, China \\ ${ }^{2}$ Department of Pharmacy, School of Health Sciences, University of Zambia, Lusaka, Zambia \\ ${ }^{3}$ Department of Pharmacy, School of Health Sciences, Levy Mwanawasa Medical University, Lusaka, Zambia \\ Email: *enalasharon@gmail.com
}

How to cite this paper: Lufungulo, E. S., Mwila, K., Mudenda, S., Kampamba, M., Chulu, M., \& Hikaambo, C. N. (2021). Online Teaching during COVID-19 Pandemic in Zambian Universities: Unpacking Lecturers' Experiences and the Implications for Incorporating Online Teaching in the University Pedagogy. Creative Education, 12, 2886-2904

https://doi.org/10.4236/ce.2021.1212216

Received: November 17, 2021

Accepted: December 25, 2021

Published: December 28, 2021

Copyright $\odot 2021$ by author(s) and Scientific Research Publishing Inc. This work is licensed under the Creative Commons Attribution International License (CC BY 4.0).

http://creativecommons.org/licenses/by/4.0/

\section{(c) (i) Open Access}

\begin{abstract}
Background: Educational institutions both private and public (schools, colleges, and universities) in Zambia are predominantly based on traditional methods (face to face) of teaching and learning. The unexpected outbreak of the coronavirus disease 2019 (COVID-19) caused by severe acute respiratory syndrome coronavirus-2 (SARS-CoV-2) disrupted and shook the entire world's formal educational ecosystem. As a result, education systems all across the world, including Zambia, were forced to switch to remote teaching based on online platforms overnight. This study was conducted to explore the experiences of lecturers in delivering lectures during the COVID-19 pandemic. Objectives of the Study: To assess the extent to which COVID-19 has influenced the lecturers' mode of teaching; to establish the lecturer's attitudes towards online teaching during the covid-19 pandemic, and to explore the lecturer's online teaching experiences and student interaction during the COVID19 pandemic. Methods: This study employed a qualitative approach and specifically the narrative design and was largely dependent on primary data. Data were collected using face to face semi-structured interviews from 16 purposefully sampled University of Zambia lecturers. The data were collected between early November and early December 2020. All interviews lasted between 40 50 minutes. The data from the interviews were recorded manually, transcribed and coded thematically. Narrative descriptions, matrixes and diagrams have been used to present and analyze the findings.
\end{abstract}




\section{Keywords}

COVID-19, Online Teaching and Learning, E-Learning, Lecturers'

Experiences, Education, Technology, Attitudes, Transactional Distance

\section{Background and Context}

The study sought to explore online teaching during the coronavirus disease 2019 (COVID-19) pandemic at the University of Zambia (UNZA) by unpacking lecturers' experiences and the implications for incorporating online teaching and learning in the university pedagogy. Three qualitative themes were generated these include: lecturers' mode of teaching before and after the COVID-19 pandemic, the lecturers' attitudes towards online teaching during the COVID-19 crisis and the lecturers' online teaching experiences and students' interactions during the COVID-19 pandemic. The paper also attempted to apply tenets of Moore's Theory of Transactional Distance in understanding the effects of the pandemic in the school of education at UNZA. The results revealed that the lecturers' mode of teaching before the COVID-19 crisis was predominantly traditional (face to face) but after the crisis lecturers were forced to shift from the traditional mode of teaching to the Online mode of teaching. Going forward lecturers indicated that the blended method should be adopted. Lecturers' initial attitudes towards Online teaching were negative however, most lectures are slowly warming up to online teaching. Lecturers indicated that their experiences with online teaching were both desirable and undesirable although the undesirable experience outweighs the desirable experiences. The study concluded that the pandemic forced lecturers to move from their traditional forms of teaching to new innovative online methods, instructions and pedagogies that promote student autonomy and keep the transactional distance between lecturers and students negligible. Furthermore, even though lecturers' initial attitudes to online teaching were negative, faulty eventually warmed up to online teaching and have currently fully embraced it notwithstanding its challenges.

Before the COVID-19 pandemic, the globe was already facing significant challenges in fulfilling the promise of education as a basic human right (United Nations, 2020). With the coming of COVID-19 challenges in the education sector have risen to unprecedented levels. For example, Universities globally have had to urgently and unexpectedly request their faculty to teach online courses they previously taught face to face (Ali, 2020; Dhawan, 2020; Rapanta, Botturi, Goodyear, \& Guardia, 2020). At UNZA, particularly the school of education, teaching staff whether Generation X (those born in analogue era), Xennials (had an analogue childhood and digital adulthood) or Millenials (digital childhood and adult) have had to urgently prepare and deliver their classes online a challenge and opportunity that cannot be evaded in the time of the COVID-19 pandemic. Driven by the impact of COVID-19 on education, various scholars and organi- 
sations have examined the COVID-19 visa vis online teaching and learning (Ali, 2020; Dhawan, 2020; Mudenda et al., 2021; Rapanta et al., 2020; United Nations, 2020; World Bank, 2021). These studies offer distinctive novel perspectives on the opportunities and challenges of online teaching and remote work and provide possible strategies and initiatives that could enhance the quality of online teaching and learning today and in the near future.

The COVID-19 pandemic has created the largest interruption of the education system in history, affecting nearly 1.6 billion learners worldwide (United Nations, 2020). Documenting lecturers' online teaching experiences, their interactions with students and attitudes towards online teaching during the COVID-19 pandemic is likely to equip and prepare lecturers globally with the necessary strategies to deal with a similar or greater future crisis that has the potential to disrupt educational processes and learning (EdTech Hub, 2020). In practice, this research could assist stakeholders such as governments and policymakers in launching, supporting, and implementing online teaching initiatives that benefit both lecturers and students in universities around the world. Intellectually, this study contributes to ongoing studies on COVID-19's impact on university teaching and learning environments. Also, the findings uncover critical areas that call for further research and contribute to local literature on the subject.

\subsection{Objectives of the Study}

1) To assess the extent to which COVID-19 has influenced the Lecturers' mode of teaching.

2) To establish lecturers' attitudes towards online teaching during the COVID-19 pandemic.

3) To explore the lecturers' online teaching experiences and student interaction during the COVID-19 pandemic

\subsection{Literature Review}

The terms (online learning, open learning, web-based learning, computer-mediated learning, blended learning, m-learning and e-learning) have in common the ability to use a computer connected to a network, that offers the possibility to learn from anywhere, anytime, in any rhythm, with any means (Cojocariu, Lazar, Nedeff, \& Lazar, 2014; Mwila, Mudenda et al., 2021). In this study, the focus is the lecturer's online teaching experiences. Therefore, online teaching is defined as teaching that is mediated by the Internet whether synchronous or asynchronous.

Although online teaching has been encouraged for many years, the COVID-19 pandemic has promoted it on a large scale ( $\mathrm{Wu}, 2021)$. Online remote teaching and learning is the most practical solution to continue teaching and learning particularly at tertiary institutions in these unprecedented times (Mazlan et al., 2021). Despite active promotion by governments, University management and school administrations, there are still many challenges educators face as they 
teach students online. In a study conducted by Dhawan (2020) findings of a SWOT (strengths, weaknesses, opportunities, and threats) analysis revealed weaknesses of online teaching during the pandemic being technical difficulties, time management issues, distractions, frustrations, anxiety and confusion, lack of personal and physical interactions. The challenges included the unequal distribution of ICTs, digital illiteracy, digital divide and poor quality education. Sarkar, Pranta Das, Rahman, and Zobaer (2021) showed that most students faced difficulty participating in virtual classes, could not communicate with their friends correctly during online classes, preferred conventional types of learning to virtual classes and did not understand the content of virtual classes easily and did not feel comfortable in online classes. Mtebe, Fulgence, and Gallagher (2021) revealed that at the University of Dar es Salaam, the availability of reliable Internet to learners and instructors remained a challenge to implementing technology-enhanced teaching. However, while lecturers could afford to buy bundles (internet services) working from home, the students could not, thereby missing out on learning. This has also been explored by other scholars (Murgatrotd, 2020; Rapanta et al., 2020) that revealed that the emergency remote online teaching exposes insufficiencies like lack of proper online teaching infrastructure, online teaching inexperiences of teachers, the information gap, the complex home and work balance, inadequate training and technical support for effective and efficient online teaching for lecturers. Most significantly, the Lecturer's little or lack of pedagogical content to teach online has also been brought to light (Murgatrotd, 2020). Although studies have been conducted by many authors recently, detailed SWOT analysis of online teaching and learning across all levels of education in Zambia has been insufficiently explored, therefore, creates an opportunity for further research.

Very recently, eminent educators and researchers have investigated strategies that could be implemented to mitigate the challenges and weaknesses of online teaching and learning. Bao (2020) for instance focused on a case of Peking University's online education suggesting five strategies that can be used to enhance online teaching. These five principles include: 1) high relevance between online instructional design and student learning, 2) effective delivery on online instructional information, 3) adequate support provided by faculty and teaching assistants to students; 4) high-quality participation to improve the breadth and depth of student's learning, and 5) a contingency plan to deal with unexpected incidents of online education (platforms.) Some of these strategies are consistent with Moore' theory of transactional distance that theories that properly designed online courses and programs lead to quality learning thereby reducing the psychology distance between the teacher and learner regardless of the physical distance being present (Moore \& Kearsley, 1996). On the other hand, Mazlan et al. (2021) also provide insights that can improve online teaching and learning experiences for both educators and students. They suggest that adopting a suitable online platform to carry out teaching and learning, using asynchronous and 
synchronous communication in online remote teaching and learning and giving feedback to increase students' motivation can positively influence the online teaching experience for the learners. Furthermore, Ali (2020) used a meta-analysis methodology to capture the essence of continued learning during these unprecedented times of Covid-19. Findings revealed that apart from resources, staff readiness, confidence, student accessibility and motivation play an important function in ICT integrated learning. These studies provide new insights on best practices of online teaching and learning that can benefit both the institutions of learning and those managing the institutions.

Rapanta et al. (2020) have shown that despite the weakness and challenges of online teaching, it is a necessary skill to be acquired by educators in their professional trajectory. They indicate that for educators in universities around the world to be competitive, evidence of faculty preparedness in terms of professionalism is necessary. Online teaching is an essential part of professional preparedness. Thus it is necessary to invest in such professionalism to be updated on effective pedagogical methods including those that involve the use of technologies. Radha, Mahalakshmi, Kumar, and Saravanakumar (2020) concluded in their study that students attitudes towards e-learning are positive despite the challenges associated with it. They further highlight that its use is even more popular due to the COVID-19 pandemic. Similarly, Dhawan (2020), revealed in the SWOT analysis that online teaching and learning support time and location flexibility caters for a wider audience, provides immediate feedback to learners, strengthens skills of problem-solving, critical thinking and adaptability and is also an innovative pedagogical approach.

The foregoing studies have emphasized that while online teaching and learning is faced with several challenges and weaknesses, it also has strengthens and benefits. Also, seeing that online teaching is the best way to ensure teaching and learning continues during the pandemic, strategies should be put in place to mitigate the problems of online teaching. As has been previously stated, the present study departs from the aforementioned studies by focusing on UNZA's school of education lecturer's online teaching experiences and student interaction during the COVID-19 pandemic. This study is also underpinned by Moore's theory of transactional distance. In this theory, Moore (1997) has theorised that the establishment of quality interaction and dialogue between the educator and the student is a critical component in breaking down barriers to success in online distance learning.

\section{Theoretical Perspective: Moore's Theory of Transactional Distance}

Moore's theory of transactional distance is one of the most utilised theories in the studies related to distance education and remote teaching (Falloon, 2011). Scholars like (Chen, 2001; Falloon, 2011; Garrison, 2000) have applied it in their studies to analyse the teacher and student transactional gaps in remote learning. Michael G. Moore describes transactional distance as "a psychological and communication space to be crossed; a space of potential misunderstanding between 
the inputs of instructor and those of the learner (Moore \& Kearsley, 1996). Instead of describing distance education or remote teaching and learning as a geographical separation between students and teachers, Moore (1997) introduced the notion of cognitive and communication distance. Moore, explains that the nature of the transaction established between the teacher and the students needs to take into account three factors namely; structure, dialogue and autonomy in online distance teaching-learning as it were. Falloon (2011) suggests that, although Moore's theory provides a useful conceptual "lens" through which to analyse online learning practices, its views may need revisiting to reflect the move towards the use of synchronous communication tools in online distance learning.

In this theory, structure deals with the way the remotely taught course is organised (its framework). It describes the extent to which an educational program can accommodate or respond to the learner's individual needs. Moore (1997) argues that the more structured the course is the more students feel constrained by the course. This increases the transactional distance (psychological separation between the teacher and the learner) as a result, teachers and learners may feel less connected to each other in remotely taught courses.

On the other hand, dialogue is the relationship of words, actions, ideas and other interactions between teachers and learners (Falloon, 2011). Giossos, Koutsouba, Lionarakis, and Skavantzos (2009) add that dialogue goes beyond the two-way communication of the teacher and learner, but considers all forms of communication within the context of clearly defined educational targets, cooperation and understanding on the part of the teacher, and eventually, it culminates in solving the learners' problems. Moore (1997) points out that what matters most is not necessarily the regularity of dialogue, but its quality. Simply put, the interactions between the teacher and learners should be of a quality standard and help the students learn. It has been theorised that the more teachers and learners communicate in remote education, whether synchronously or asynchronously, the lesser the transactional distance.

Achieving student autonomy is contingent upon the structure and dialogue status of any program in that it refers to the sense of both independence and interdependence perceived by learners as they engage in the course (Moore, 1997). The Learner's autonomy is the learner's sense of self-direction or self-determination, which can fundamentally be affected by the dialogue between the teacher and learner (Falloon, 2011). As the educator plans the course, the framework should provide for the learner's autonomy. The level of rigidity or flexibility inherent in the course design and delivery and the extent to which the learner exerts control over learning procedures determines their level of autonomy (Giossos et al., 2009). Therefore, according to Moore, learner autonomy is achieved when the course is less structured but has increased dialogue.

Moore's theory asserts that an inverse relationship exists between these three factors. When course structure drops below a particular threshold, the sense of transactional distance (misunderstanding between the inputs of the teacher and 
the learner) can increase leading to learner confusion or dissatisfaction (Falloon, 2011). When the transactional distance is wide the quality of learning is principally compromised.

Figure 1 below shows the inverse relationships between the three variables of transactional distance structure, dialogue and autonomy. The graph also highlights different programs and how each of them affects the transactional distance between the teacher and the learner. For example, the graph shows that learners' tutorials are less structured but involve more dialogue between the teacher and learner hence reducing the transactional distance. Lecturer' experiences of online teaching during the COVID-19 pandemic have the potential to measure the transactional distance between the instructors and students. Measuring the transactional distance is essential because the quality of education and learning taking place can be determined. This study also examined the COVID-19 pandemic with a focus on lecturers experience with online teaching in the school of education at UNZA.

\section{Methodology and Design}

\subsection{Study Design}

This study employed a qualitative research approach and a narrative design. A narrative inquiry can reveal unique perspectives and a deeper understanding of a situation (Liamputtong, 2009). Narrative inquiry records the experiences of an individual or small group, revealing the lived experience or particular perspective of that individual, usually primarily through interviews, which are then recorded and transcribed to generate meaningful themes (Padgett, 2012). Defining features of the narrative approach include the collection of narratives (stories)

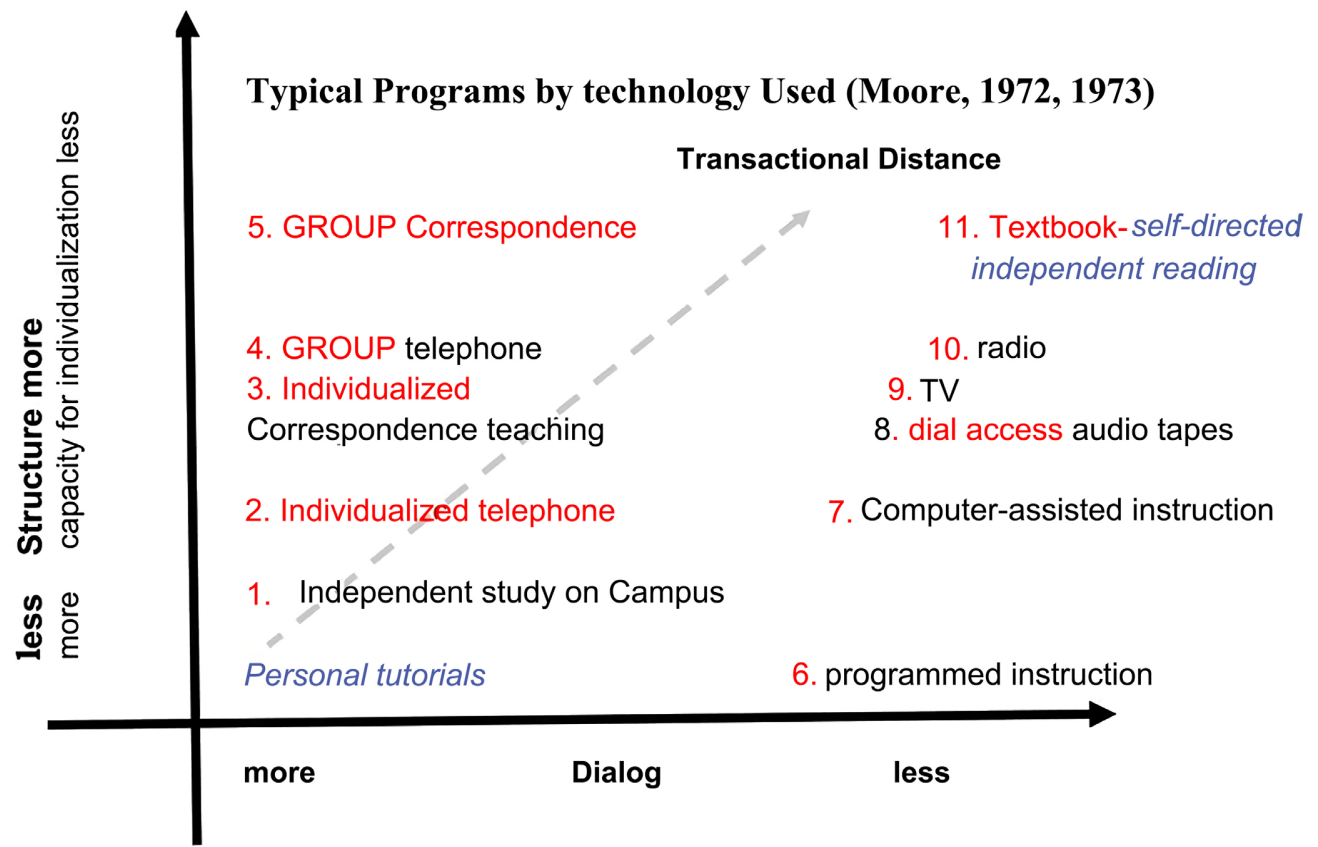

Figure 1. Moore's transactional distance Source: https://k3hamilton.com/LTech/transactional.html. 
from individuals or small groups. Most often there is a collaboration with the researcher as storytelling engages the audience. These stories tell of individual experiences that often exposes the researcher to the identities of that individual. Narratives are often collected through interviews but other qualitative forms of data collection, such as observations and documents may be used. Analysis of narrative data varies as there is no universal approach however narrative researchers have published guidelines and processes (Reissman, 2008). The narrative data analysis process should be selected based on your purpose and research questions (Creswell, 2013). To that effect, lecturers expressed their lived experiences of online teaching through face-to-face interviews.

\subsection{Sample Size and Sampling Technique}

Face-to-face semi-structured interviews were used to collect data from 16 purposively selected University of Zambia, School of Education lectures. Bernard (2002) explains that purposeful sampling, also known as purposive and selective sampling, is a sampling technique that qualitative researchers use to recruit participants who can provide in-depth and detailed information about the phenomenon under investigation. Participation in the study is determined by the qualitative researcher generating the qualifying criteria each participant must meet to be considered for the research study. Therefore, the lecturers targeted in this study were from the school of education. The school of education is the biggest school at the University of Zambia in terms of student enrollment and faculty members. Hence, the experiences of online teaching of the lecturers in the school were of utmost importance in profiling how lecturers were generally adapting to the new mode of teaching.

\subsection{Data Collection}

The data was collected between early November and early December 2020. All interviews lasted between 40 - 50 minutes. The semi-structured face to face interviews was used to collect data from the respondents. Mwila, Kalolo, Mudenda, and Hikaambo (2021) argue that the method is advantageous because it allows direct questions to respondents about their activities. Semi-structured interviews were chosen because of their flexibility in addressing more specific issues, eliciting interpretations from respondents, following up on points that were not clear in the respondents' narrations, and probing where necessary. The interview guide also helped the researcher to be more systematic and to keep track of the goals of the study.

\subsection{Data Analysis}

Framework analysis was used to analyze the data. In the analysis stage, the gathered data was sifted, charted and sorted per key issues and themes. The themes were identified and drawn from the responses to the questions given by the respondents. The framework approach offers the researcher a systematic structure 
to manage, analyze and identify themes, enabling the development and maintenance of a transparent audit trail (Fugard \& Potts, 2015). It is particularly useful with large volumes of text and is suitable for use with different qualitative approaches. Mwila, Lufungulo et al. (2021) elude that the Framework analysis is flexible during the analysis process in that it allows the user to either collect all the data and then analyze it or do data analysis during the collection process. Framework, narrative descriptions, matrixes and diagrams have been used to present and analyse the findings. Secondary sources of data (Journals, Reports, Search Engines, Scholarly Articles and Research Papers) were also reviewed.

\section{Results}

\subsection{Participants' Social Demographic Characteristics}

The participants' characteristic matrix Table 1, shows their pseudo names, gender, their approximate age and the years of service (school of Education, UNZA), speciality and date of the interview. Most participants were male and aged above 30 years with work experience in the teaching of more than 5 years.

'Table 1. Participants' characteristics matrix.

\begin{tabular}{|c|c|c|c|c|c|}
\hline Pseudo name & Gender & Age & $\begin{array}{c}\text { Years } \\
\text { of service }\end{array}$ & Speciality & $\begin{array}{c}\text { Date } \\
\text { of interview }\end{array}$ \\
\hline Ms XR & $\mathrm{F}$ & Early 30s & 5 years & Curriculum Studies & 5 Nov. 2020 \\
\hline Mr XD & M & Mid 30s & 10 years & Literacy \& Language & 6 Nov. 2020 \\
\hline Dr XP & M & Early 50 s & Over 25 years & $\begin{array}{l}\text { Psychology } \\
\text { of Education }\end{array}$ & 18 Nov. 2020 \\
\hline Mrs XB & $\mathrm{F}$ & Early $40 \mathrm{~s}$ & 10 years & Home Economics & 19 Nov. 2020 \\
\hline Mr XO & M & Late 20 s & 4 years & ICT \& Education & 20 Nov. \\
\hline Mrs XL & $\mathrm{F}$ & Early $40 \mathrm{~s}$ & 15 years & Library \& Information & 30 Nov. 2020 \\
\hline Mr XC & M & Mid 40s & 10 years & Teaching methods & 4 Dec. 2020 \\
\hline Ms XF & $\mathrm{F}$ & Late 30 s & 7 years & Sports studies & 4 Dec. 2020 \\
\hline Prof XQ & M & Late $50 \mathrm{~s}$ & Over 25 years & Religious Education & 7Dec 2020 \\
\hline Dr XM & $\mathrm{F}$ & Late 40 s & 10 years & Educational Planning & 7Dec 2020 \\
\hline Dr XG & $\mathrm{F}$ & Early50s & 22 years & Special Education & 8Dec 2020 \\
\hline MR XY & M & Mid 30s & 9 years & $\begin{array}{l}\text { Educational } \\
\text { Management }\end{array}$ & 10Dec 2020 \\
\hline Dr XZ & M & Late 40 s & 20 years & $\begin{array}{c}\text { Economics of } \\
\text { Education }\end{array}$ & 11Dec 2020 \\
\hline Mrs XV & $\mathrm{F}$ & Mid40s & 18 years & Adult Education & 11Dec 2020 \\
\hline Dr XM & M & Early40s & 17 years & $\begin{array}{l}\text { Mathathematics } \\
\text { Education }\end{array}$ & 12 Dec 2020 \\
\hline Dr XC & M & Early 40s & 10 years & Teaching methods & $12 \operatorname{Dec} 2020$ \\
\hline
\end{tabular}




\subsection{Influence of COVID-19 on Mode of Teaching}

Most participants responded that they were using face-to-face modes of teaching before the COVID-19 pandemic and incorporated online learning during the pandemic. Conversely, all the participants recommended that blended learning be the style of teaching in future as shown in Table 2.

\subsection{Lecturers' Attitudes towards Online Teaching during the COVID-19 Pandemic}

Figure 2 shows that the majority of the participants had a negative attitude towards the introduction of online learning in the initial stages of its introduction.

\subsection{Lecturers' Online Teaching Experiences and Students' Interactions during COVID-19 Crisis}

Figure 3 shows the experiences of lecturers during the introduction of online teaching in the COVID-19 era. The flow chart shows that the lecturers' experiences and their interactions with students were both desirable and undesirable. The undesirable experiences included, technical difficulties, students low capabilities

Table 2. Role ordered Interviewee's matrix; COVID-19 influence on the mode of teaching.

\begin{tabular}{|c|c|c|c|c|c|c|}
\hline Research Qu & uestion (1 & )-How & has COV & ID-19 influenced the lecturer's mod & de of teaching? & \\
\hline Interviewee & Gender & Age & $\begin{array}{l}\text { Years of } \\
\text { service }\end{array}$ & Mode of teaching prior COVID-19 & $\begin{array}{l}\text { Mode of teaching DURING } \\
\text { COVID-19 }\end{array}$ & $\begin{array}{l}\text { Mode of teaching } \\
\text { beyond COVID-19 }\end{array}$ \\
\hline $\mathrm{X} 1$ & $\mathrm{~F}$ & $30-40$ & 7 & Online teaching was non-existent & Urgently had to teach online. & Blended \\
\hline $\mathrm{X} 2$ & M & $40-50$ & 10 & Traditional on-site teaching dominant & Online teaching & Blended \\
\hline $\mathrm{X} 3$ & M & $40-50$ & 15 & Face to face lectures dominated & $\begin{array}{l}\text { Interacted virtually with } \\
\text { students }\end{array}$ & $\begin{array}{l}\text { Blended with most } \\
\text { of it being onsite }\end{array}$ \\
\hline $\mathrm{X} 4$ & $\mathrm{~F}$ & $20-30$ & 4 & Blended method & Intensified online teaching & Blended \\
\hline $\mathrm{X} 5$ & M & $40-50$ & 10 & $\begin{array}{l}\text { Little to no online teaching face to } \\
\text { face dominated }\end{array}$ & $\begin{array}{l}\text { Had to transition to online } \\
\text { teaching }\end{array}$ & Blended \\
\hline $\mathrm{X} 6$ & $\mathrm{~F}$ & $40-50$ & 25 & Traditional face to face teaching only & No choice but to teach online & Blended \\
\hline $\mathrm{X} 7$ & M & $30-40$ & 10 & Face to face teaching dominated & Online teaching & Blended \\
\hline $\mathrm{X8}$ & $\mathrm{F}$ & $30-40$ & 5 & Face to face interactions & Online teaching & Blended \\
\hline X9 & M & $50-60$ & 25 & Traditional face to face teaching only & Online teaching & Blended \\
\hline $\mathrm{X} 10$ & $\mathrm{~F}$ & $40-50$ & 20 & Face to face lectures dominated & Online teaching & Blended \\
\hline $\mathrm{X} 11$ & $\mathrm{~F}$ & $50-60$ & 25 & Face to face lectures dominated & Online teaching & Blended \\
\hline $\mathrm{X} 12$ & M & $30-40$ & 9 & $\begin{array}{l}\text { Little to no online teaching face to } \\
\text { face dominated }\end{array}$ & Intensified online teaching & Blended \\
\hline $\mathrm{X} 13$ & M & $40-50$ & 14 & Blended method & Urgently had to teach online. & Blended \\
\hline $\mathrm{X} 14$ & $\mathrm{~F}$ & $30-40$ & 14 & Blended method & Resorted to teaching online. & Blended \\
\hline $\mathrm{X} 15$ & M & $40-50$ & 18 & Face to face lectures dominated & Resorted to Online teaching & Blended \\
\hline $\mathrm{X} 16$ & M & $40-50$ & 17 & Traditional face to face teaching only & Adopted online teaching & Blended \\
\hline
\end{tabular}




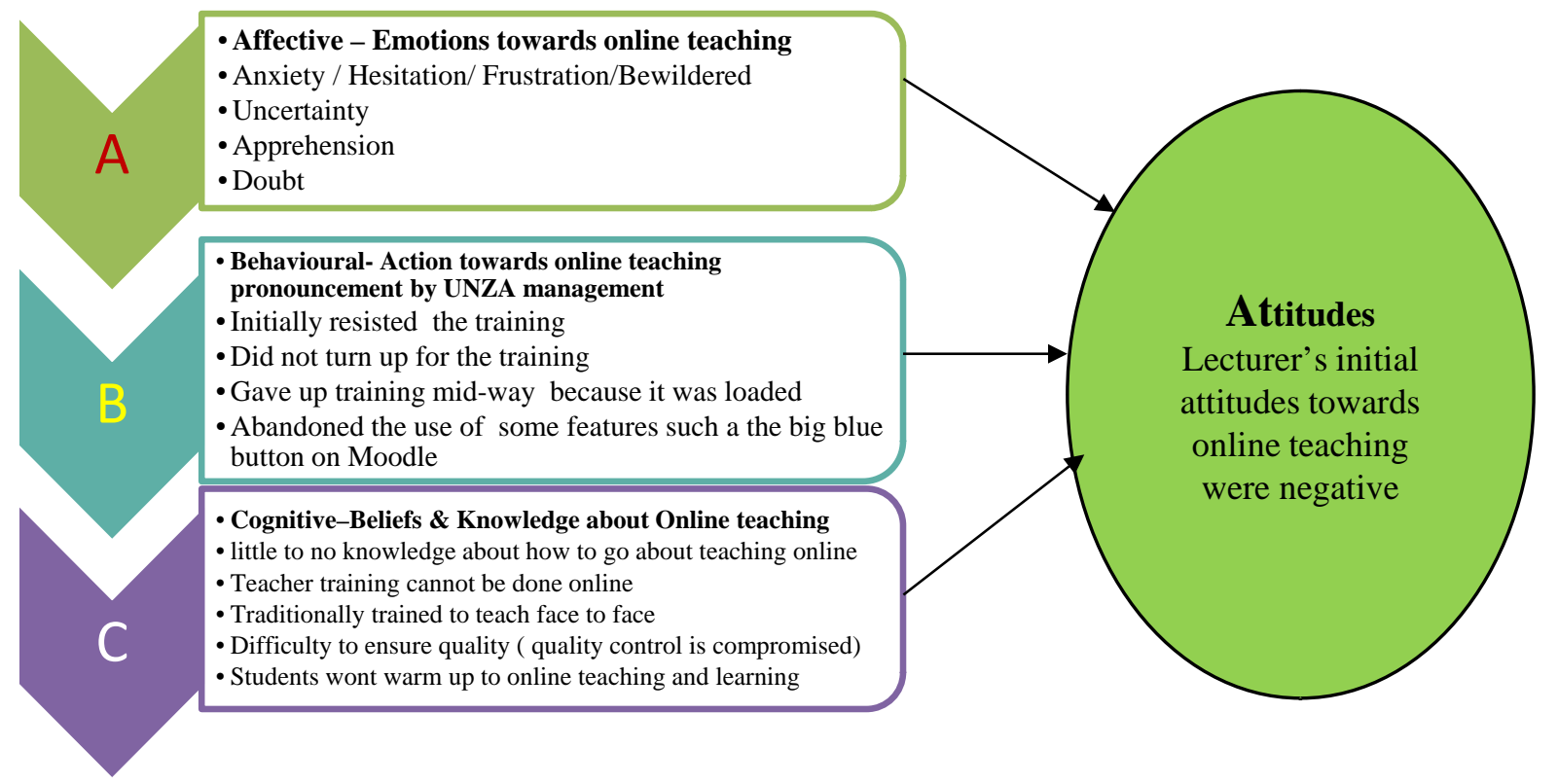

Figure 2. Lecturer's ABC model of attitudes towards online teaching during the COVID-19 pandemic: initial attitudes.

and confidence levels, time management, distractions during classes caused by connectivity issues, and lack of physical interactions with the students. In addition, lecturers indicated that poor ICT infrastructure, students economic status, digital illiteracy, digital divide, unsatisfactory online teaching training and lack of it and technology cost resulting in learning loses which subquently affected the quality of education. While lecturers faced challenges they also stated that online teaching was good for them as they could teach from anywhere at any time. In addition, they indicated that the pandemic was a blessing in disguise. Lecturers revealed that they were exposed to online teaching skills and competencies and had the opportunity to develop productive and versatile qualities. As a result, their teaching experiences were improved due to their exposure to $21^{\text {st }}$-century ICT skills.

\section{Discussion}

This study explored the experiences of lecturers in the school of education at UNZA from face-to-face teaching methods to online teaching. The COVID-19 pandemic has created the largest interruption of the education system in history, affecting nearly 1.6 billion learners worldwide (United Nations, 2020). Documenting lecturers' online teaching experiences, their interactions with students and attitudes towards online teaching during the covid1-19 pandemic is likely to equip and prepare lecturers globally with the necessary strategies to deal with a similar or greater future crisis that has the potential to disrupt educational processes and learning.

\subsection{Lecturers' Mode of Teaching before and during the COVID-19 Pandemic}

Plans to roll out online teaching and learning at the University of Zambia go 


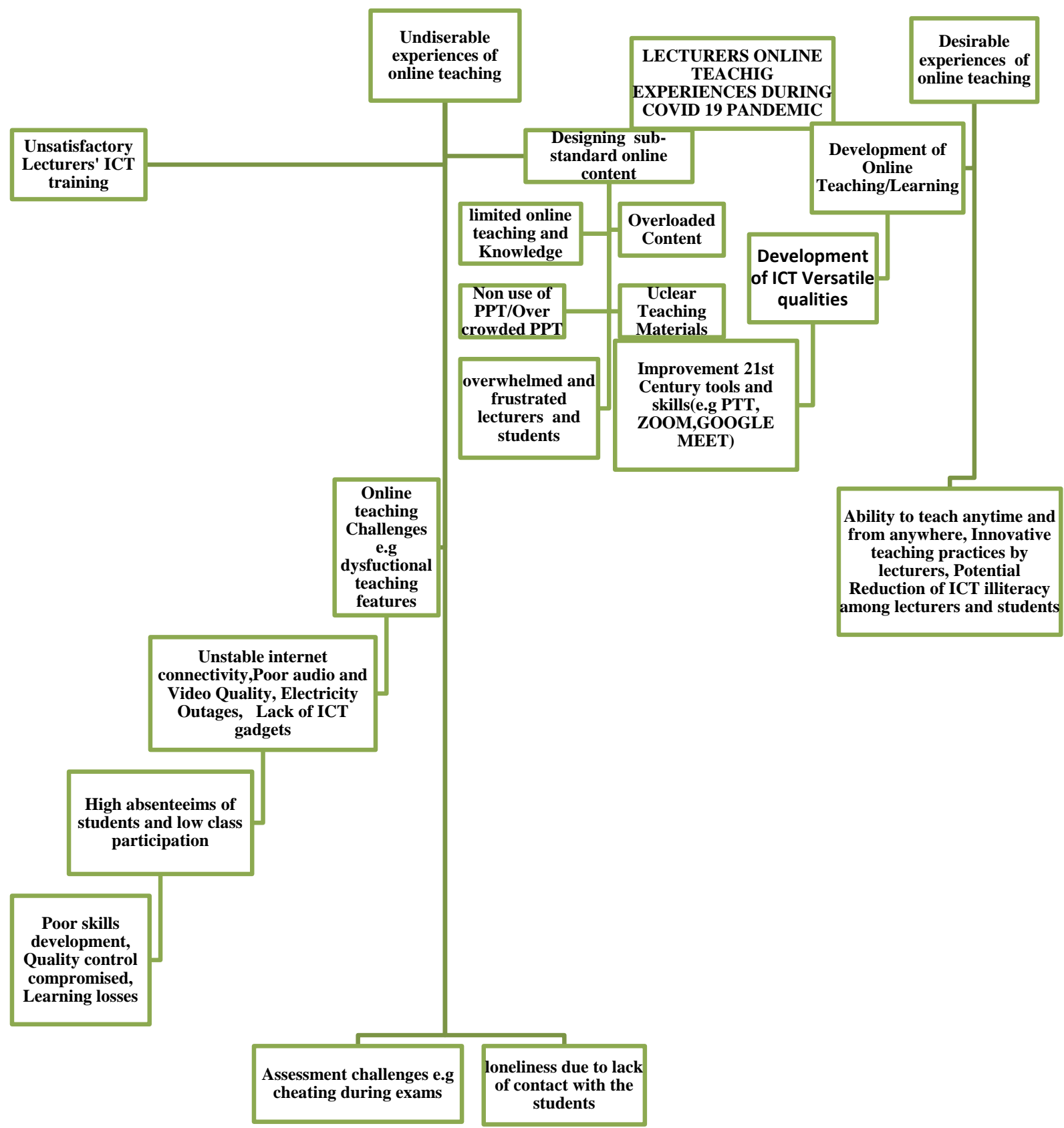

Figure 3. A Flow chart of lecturer's online teaching experiences and students' interactions during COVID-19 crisis.

back several years. The plans are stated in the University of Zambia's strategic plans 2013-2017 and 2018-2020. In the strategic plan 2013-2017 particularly strategic direction 7 , the goal was to expand and promote the use of information and communication technologies across campuses by improving among other things internet connectivity. In the 2018-2020 strategic plan, objective number 1.2 stated that by 30 June 2020, the University will have implemented a fully-fledged e-learning platform for all University programmes.

Despite the University's efforts of introducing e-learning platforms like the moodle platform, the findings of this study as shown in Figure 3 are indicative 
of the fact that lecturers did not easily warm up to the idea of teaching online before the COVID-19 pandemic. For example, one of the participants stated that;

"before the COVID-19 pandemic, there was a call for us to move toward elearning to use the moodle platform, but am one of those who did not warm up to the idea but when the covid-19 problem came, it became urgent we did not have a choice anymore but to use online teaching tools."

This situation is not unique to the UNZA only, recent scholarship and reports have indicated that globally, Universities mostly, taught face to face but moved all their courses online due to the COVID-19 crisis. Rapanta et al. (2020) elude that a particular challenge caused by the COVID-19 was the urgent and unexpected request for previously face-to-face university courses to be taught online. However, transitioning from face-to-face teaching is does not occur easily as teachers and students may face different challenges (Mpungose, 2020). Besides, replacing face-to-face teaching with e-learning methods may not be possible because face-to-face learning is the cornerstone of teaching in every university despite the need for e-learning methods (Liu \& Long, 2014; Nikoubakht \& Kiamanesh, 2019). In essence, students that attended school regularly were forced to adjust to distance or remote mode of learning away from the face-to-face system they are used to. In essence, online distance education became the only option. This is in tandem with a study that was done in South Africa in which transitioning to online teaching methods was the only option due to the disruption of physical classes caused by COVID-19 (Mpungose, 2020). Online distance education hinges on communication and technology as its bedrock. It involves two-way communication between (among) teacher and student(s) to facilitate and support the educational process (Choudhury \& Pattnaik, 2020). Moore (1997) in his theory notes that distance education or remote learning when hastily and improperly organised could lead to transactional distance between the teachers and learners which ultimately affects learning outcomes. Conversely, e-learning helps continuity of education in the absence of face-to-face teaching methods (Kemp \& Grieve, 2014; Waghid, 2018). It is for this reason that lecturers embrace e-learning methods during the COVID-19 pandemic.

\subsection{Lecturers' Attitudes towards Online Teaching during the COVID-19 Crisis}

Findings from the interviews reveal that lecturers' initial attitudes towards online teaching in the early days of the Covid-19 pandemic were implicitly negative. Interviewees indicated that they were anxious, uncertain, confused, apprehensive and doubted the effectiveness of urgent online teaching and student interaction. Interviewees further stated that because they were trained to handle face to face traditional classrooms, they had little to no knowledge of how to handle online classes and were hesitant to teach online. It was from this background that Mwila, Mudenda et al. (2021). Suggested that Lecturers should do computer refresher courses to conduct online lectures effectively. The Lecturer's lack of pedagogical content knowledge to teach online took most of them off 
balance. Ching, Hsu, and Baldwin (2018) posits that a significant challenge for university teachers has been their lack of pedagogical content knowledge (PCK) needed for teaching online. Rapanta et al. (2020) add that more significantly, lecturers lack pedagogical fundamentals and knowledge needed to design for, and facilitate meaningful online learning experiences. As a result, it has added to the stresses and workloads experienced by university faculty and staff who were already struggling to balance teaching, research and service obligations, not to mention the work-life balance (Houlden \& Veletsianos, 2020; Houston, Meyer, \& Paewai, 2006). The lecturer's initial negative attitudes towards online teaching affected the online teaching quality. One of the respondents indicated that

"I had problems recording quality videos later on uploading them online because most of them were very big and also the internet was sometimes erratic. The lessons also tended to be non-student-centred as a result students were disadvantaged"

The scenario portrayed above has the potential of affecting the course structure negatively. Moore (1997) notes that when course structure drops below a particular threshold, the sense of transactional distance can increase, due principally to the potential for learner confusion or dissatisfaction. When the transactional distance increase the quality of teaching and learning is compromised.

While the study revealed that lecturers' initial attitudes towards online teaching were negative, the study also shows that lecturers eventually warmed up to the idea of teaching online classes especially after realising that COVID-19 might not go away any time soon. One of the participants indicated that;

I enjoy online teaching because it has equipped me and my students with $21^{\text {st }}$ century teaching and learning skills. That's why I say that the coronavirus is a blessing in disguise. Without it, I would still be lagging when it comes to online teaching skills.

Another participant indicated that:

After training and teaching myself how to navigate the online teaching platforms, I have learnt to be creative, I post audios using google drive, I have learned how to link external videos to moodle and I have devised a way of staying connected with my students via WhatsApp an app that is student-friendly.

Lecturer's positive attitudes towards online teaching are vital in the process of remote online teaching because as Falloon (2011) indicates, teachers' confidence in online teaching leads to their ability to design online suited courses that have the potential to increase dialogue between the teacher and learner and also improves learner's autonomy and eventually learning outcomes. Ali (2020) indicates that Meta-synthesis exposes that willingness to embrace change is a major requirement for successful integration of technology as it provides students and lecturers opportunities to learn and apply the required 21st-century skills.

\subsection{Lecturers' Online Teaching Experiences and Students' Interactions during Covid-19 Pandemic}

Results show that the lecturer's experiences with online teaching at the School of 
education UNZA are both desirable and undesirable. The desirable experiences can be attributed to the versatility of online teaching and learning resources and the mere fact that online teaching is not limited by time and space provided one has proper internet connectivity. Similarly, Ali (2020) points out that online learning environments foster experiences where learners can interact, collaborate, and take ownership of their learning at their own pace and time. Henceforth, ICT wrapped lessons provide an inspiring and reassuring learning environment for both lecturers and students and also it leads to self-directed learning. According to Moore (1997) self-directed learning resulting from a properly and flexible structured course reduces the transactional distance between the teacher and learner thereby necessitating healthy learning environments.

On the other hand, the undesirable experiences highlighted in Figure 3 are a result of a spectrum of interconnected challenges ranging from the University's inability to support and provide proper ICT infrastructure and resources for both lecturers and students, to student's inability to attend classes due to social-economic inequalities and poverty.

These findings are similar to those of (Mwila, Mudenda et al., 2021) who argue that successful and sustainable e-learning implementation remains a challenge, particularly in ICT-challenged environments. Internet challenges make it difficult to conduct and attend online learning. It was notable that students from rural districts of Zambia were faced with the critical challenge of poor internet connectivity. Poor internet connectivity is a hindrance to quality education among students coming from rural areas.

The lecturer bemoaned the inability of students to attend class due to a lack of ICT gadgets and money to connect to the internet. This is further supported by (Mwila, Mudenda et al., 2021) who elude that students in rural parts of Zambia described online learning as a financial burden associated with the cost of mainly their inability to buy good Android operating system-based smartphones and laptops. The cost was also mainly incurred from buying internet data bundles.

Others lamented that teacher training and other practical subjects such as sports and sciences cannot be done online, thus the absence of face-to-face teaching compromises the quality of students graduating. One of the Interviewees indicated that:

Online teaching can sometimes be very lonely especially when you can't see your student. It feels like you are speaking to yourself or the wall.

Dhawan (2020) reveals similar results by highlighting that Online teaching has weaknesses such as technical difficulties, lack of personal and physical attention that leads to loneliness to both the educators and learners. Challenges and weakness withstanding, (Zalat, Hamed, \& Bolbol, 2021) in their study revealed that staff members at their University agreed that the online course design permits staff educate at their speed and that technological skills acquired from teaching online courses increased their educational experience.

This section presented a discussion of the findings of the study by highlighting 
key thematic areas these included: Lecturer's mode of teaching before and during the COVID-19 pandemic; under this theme, it was established that despite the University's efforts of introducing e-learning platforms like the moodle platform, the findings revealed the fact that lecturers did not easily warm up to the idea of teaching online before the COVID-19 pandemic.

Additionally, on Lecturer's attitudes towards online teaching during the covid-19 crisis, revealed that lecturers' initial attitudes towards online teaching in the early days of the Covid-19 pandemic were implicitly negative. And lastly on Lecturer's online teaching experiences and students' interactions during the Covid-19 pandemic revealed lecturer's experiences with online teaching at the School of education UNZA are both desirable and undesirable.

\section{Conclusion}

The study has established that despite its devastating effects on humanity in general and specifically on education systems globally, COVID-19 has been a blessing in disguise. For the school of education at UNZA, the pandemic has been a catalyst at ensuring that the UNZA achieves its strategic plan 2018-2020, objective number 1.2 which states that by 30 June 2020 , the University will have implemented a fully-fledged e-learning platform for all University programmes. The pandemic forced lecturers to move from their traditional forms of teaching to new innovative online methods, instructions and pedagogies. Even though lecturers' initial attitudes to online teaching were negative and faulty lecturers eventually warmed up to online teaching and have currently fully embraced it notwithstanding its challenges. The study has also shown that lecturers' undesirable teaching experiences emerged from a spectrum of issues ranging from managements failure to provide basic online teaching-learning tools, to students inability to properly and fully participate in the online classes. A takeaway message is that both lecturers and students (of the school of education at the University of Zambia) have had to equip themselves with $21^{\text {st }}$-century teaching and learning e-education competencies. Most significantly, lecturers have learnt and are still learning to design content that is suitable for online teaching and learning. Content promotes student autonomy so that the transactional distance between lecturers and learners is kept minimal during the period of the COVID-19 pandemic today and in the unforeseen future.

\section{Recommendations}

1) Further research is recommended to conduct an extensive study encompassing other schools in the University to further explore the assertions made in the present study.

2) The University management in collaboration with the government should provide a reliable network infrastructure that supports online teaching and learning. Strategies and remedies (e-learning tools and software) to mitigate challenges faced by faculty in the delivery of online lessons during the pandemic and 
beyond should be implemented.

3) Systematic and efficient training initiatives should be provided to improve lecturers and students technological skills concerning new emerging models and approaches encouraging effective online lessons.

\section{Acknowledgements}

We are thankful to all the participants for being part of this study.

\section{Conflicts of Interest}

The authors declare no conflicts of interest regarding the publication of this paper.

\section{References}

Ali, W. (2020). Online and Remote Learning in Higher Education Institutes. A Necessity in Light of COVID-19 Pandemic. Higher Education Studies, 10, 16-25. https://doi.org/10.5539/hes.v10n3p16

Bao, W. (2020). COVID-19 and Online Teaching in Higher Education: A Case Study of Peking University. Human Behaviour and Emerging Technology, 2, 113-115.

https://doi.org/10.1002/hbe2.191

Bernard, H. R. (2002). Research Methods in Anthropology: Qualitative and Quantitative Approaches (3rd ed.). Alta Mira Press.

Chen, Y.-J. (2001). Dimensions of Transactional Distance in World Wide Web Learning Environment: A Factor Analysis. British Journal of Educational Technology, 54, 459-470. https://doi.org/10.1111/1467-8535.00213

Ching, Y. H., Hsu, Y. C., \& Baldwin, S. (2018). Becoming an Online Teacher: An Analysis of Prospective Online Instructors' Reflections. Journal of Interactive Learning Research, 29, 145-168.

Choudhury, S., \& Pattnaik, S. (2020). Emerging Themes in E-Learning: A Review from the Stakeholders' Perspective. Computers \& Education, 144, Article ID: 103657. https://doi.org/10.1016/j.compedu.2019.103657

Cojocariu, V. M., Lazar, I., Nedeff, V., \& Lazar, G. (2014). SWOT Analysis of E-Learning Educational Services from the Perspective of Their Beneficiaries. Procedia-Social and Behavioral Sciences, 116, 1999-2003.

Creswell, J. W. (2013). Qualitative Inquiry and Research Design: Choosing among Five Approaches. Sage.

Dhawan, S. (2020). Online Learning a Panacea in the Time of COVID-19 Crisis. Journal of Education Technology, 49, 5-22. https://doi.org/10.1016/j.sbspro.2014.01.510

EdTech Hub (2020). The Effect of Covid-19 on Education in Africa and Its Implications for the Use of Technology: A Survey of the Experience and Opinions of Educators and Technology Specialists. EdTech Hub.

Falloon, G. (2011). Making the Connection: Moore's Theory of Transactional Distance and Its Relevance to the Use of a Virtual Classroom in Postgraduate. Online Teacher Education, 43, 187-209. https://doi.org/10.1080/15391523.2011.10782569

Fugard, A. J., \& Potts, H. W. (2015). Supporting Thinking on Sample Sizes for Thematic Analyses: A Quantitative Tool. International Journal of Social Research Methodology, 18, 669-684. https://doi.org/10.1080/13645579.2015.1005453 
Garrison, R. (2000). Theoretical Challenges for Distance Education in the 21st Century: A Shift from Structural to Transactional Issues. International Review of Research in Open and Distance Learning, 1, 1-17. https://doi.org/10.19173/irrodl.v1i1.2

Giossos, Y., Koutsouba, M., Lionarakis, A., \& Skavantzos, K. (2009). Reconsidering Moore's Transactional Distance Theory. European Journal of Open Distance and ELearning, 2, 1-6. http://www.eurodl.org/?article=374

Houlden, S., \& Veletsianos, G. (2020, March 12). Coronavirus Pushes Universities to Switch to Online Classes but Are They Ready? The Conversation.

https://theconversation.com/coronavirus-pushes-universities-to-switch-to-online-class es-but-are-they-ready-132728

Houston, D., Meyer, L. H., \& Paewai, S. (2006). Academic Staff Workloads and Job Satisfaction: Expectations and Values in Academe. Journal of Higher Education Policy and Management, 28, 17-30. https://doi.org/10.1080/13600800500283734

Kemp, N., \& Grieve, R. (2014). Face-to-Face or Face-to-Screen? Undergraduates' Opinions and Test Performance in Classroom vs. Online Learning. Frontiers in Psychology, 5, Article No. 1278. https://doi.org/10.3389/fpsyg.2014.01278

Liamputtong, P. (2009). Qualitative Research Methods. Oxford University Press.

Liu, C., \& Long, F. (2014). The Discussion of Traditional Teaching and Multimedia Teaching Approach in College English Teaching. In Proceedings of the 2014 International Conference on Management, Education and Social Science (pp. 31-33). https://doi.org/10.2991/icmess-14.2014.9

Mazlan, A. F., Mohamad, M., Reesha, A., Kassim, R., Othman, Z., \& Kummin, S. (2021). Challenges and Strategies to Enhance Online Remote Teaching and Learning by Tertiary Institution Educators: A Literature Review. Creative Education, 12, 718-726. https://doi.org/10.4236/ce.2021.124050 https://www.scirp.org/journal/ce

Moore, M. (Ed.) (1997). Theory of Transactional Distance. Routledge.

Moore, M., \& Kearsley, G. (1996). Distance Education: A Systems View. Wadsworth Publishing Company.

Mpungose, C. B. (2020). Emergent Transition from Face-to-Face to Online Learning in a South African University in the Context of the Coronavirus Pandemic. Humanities and Social Sciences Communications, 7, Article No. 113. https://doi.org/10.1057/s41599-020-00603-X

Mtebe, J. S., Fulgence, K., \& Gallagher, M. S. (2021). COVID-19 and Technology Enhanced Teaching in Higher Education in Sub-Saharan Africa: A Case of the University of Dar es Salaam, Tanzania. Journal of Learning for Development, 8, 383-397.

Mudenda, S., Mukosha, M., Mwila, C., Saleem, Z., Kalungia, A. C., Munkombwe, D. et al. (2021). Impact of the Coronavirus Disease on the Mental Health and Physical Activity of Pharmacy Students at the University of Zambia: A Cross-Sectional Study. International Journal of Basic \& Clinical Pharmacology, 10, 324-332. https://doi.org/10.18203/2319-2003.ijbcp20211010

Murgatrotd, S. (2020). COVID-19 and Online Learning. https://www.researchgate.net/publication/339784057 COVID-19 and Online Learning

Mwila, K., Kalolo, F., Mudenda, S., \& Hikaambo, C. N. (2021). Impact of COVID-19 on Academic Activities of Final Year Nursing Students: A Zambian Reflection. International Journal of Basic \& Clinical Pharmacology, 10, 806-812. https://doi.org/10.18203/2319-2003.ijbcp20212377

Mwila, K., Lufungulo, E. S., Masaiti, G., Mudenda, S., Kampamba, M., Mufwambi, W., Phiri, M., \& Hikaambo, C. N. A. (2021). Abolishment of Students' Meal Allowances at 
the University of Zambia: Exploring the Alternative Sources of Income, Challenges and Opportunities for First-Year Students. Creative Education, 12, 2733-2751. https://doi.org/10.4236/ce.2021.1211202

Mwila, K., Mudenda, S., Kampamba, M., Mufwambi, W., Lufungulo, E. S., Phiri, M., \& Hikaambo, C. N. (2021). Factors Affecting Access to E-Learning during the Coronavirus Disease 2019 Pandemic among Rural-Based Pharmacy Students in Zambia: A Qualitative Study. The Open Epidemiology Journal, 6, 20-29.

https://doi.org/10.17140/EPOJ-6-124

Nikoubakht, A., \& Kiamanesh, A. (2019). The Comparison of the Effectiveness of Computer-Based Education and Traditional Education on the Numerical Memory in Students with Mathematics Disorder. Journal of Psychological Science, 18, 55-65.

Padgett, D. (2012). Qualitative and Mixed Methods in Public Health. SAGE. https://doi.org/10.4135/9781483384511

http://ezproxy.deakin.edu.au/login?url=http://search.ebscohost.com/login.aspx?direct=

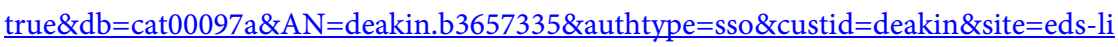
ve\&scope $=$ site

Radha, R., Mahalakshmi, K., Kumar, V. S., \& Saravanakumar, A. R. (2020). E-Learning during Lockdown of Covid 19 Pandemic: A Global Perspective. International Journal of Control and Automation, 13, 1088-1099.

Rapanta, C., Botturi, L., Goodyear, P., \& Guardia, M. K. (2020). Online University Teaching during and after the COVID-19 Crisis: Refocusing Teacher Presence and Learning Activity. Postdigital Science and Education, 2, 923-945.

https://doi.org/10.1007/s42438-020-00155-y

Reissman, C. K. (2008). Narrative Methods for the Human Sciences. Sage.

Sarkar, S. S., Pranta Das, P., Rahman, M. M., \& Zobaer, M. S. (2021). Perceptions of Public University Students towards Online Classes during COVID-19 Pandemic in Bangladesh. Frontiers in Education, 6, Article ID: 703723.

https://doi.org/10.3389/feduc.2021.703723

United Nations (2020). Policy Brief Education during COVID-19 and beyond. United Nations.

Waghid, F. (2018). Action Research and Educational Technology: Cultivating Disruptive Learning. South African Journal of Higher Education, 32, 1-11. https://doi.org/10.20853/32-4-3097

World Bank (2021, March 30). Mission: Recovering Education in 2021. https://www.worldbank.org/en/topic/education/brief/mission-recovering-education-in $\underline{-2021}$

Wu, S.-Y. (2021). How Teachers Conduct Online Teaching During the COVID-19 Pandemic: A Case Study of Taiwan. Frontiers in Education, 6, Article ID: 675434. https://doi.org/10.3389/feduc.2021.675434

Zalat, M. M., Hamed, M. S., \& Bolbol, S. A. (2021). The Experiences, Challenges, and Acceptance of E-Learning as a Tool for Teaching during the COVID-19 Pandemic among University Medical Staff. PLoS ONE, 16, Article ID: e0248758.

https://doi.org/10.1371/journal.pone.0248758 